\title{
Determination of Normal Ranges of T3, T4, FT4 \& TSH in Healthy Individuals of NINMAS by Using Korea and China Kits
}

\author{
Israque Hossain Ansari, Mizanul Hasan, Mohammad Anwar-ul Azim, Haroun-or-Rashid, Sakera Khatun,
}

Zakir Hossain and Mustafa Mamun

National Institute Nuclear Medicine and Allied Sciences

Correspondence Address : Md. Israque Hossain Ansari, Chief Scientific Officer \& Head, in vitro Nuclear Medicine Division, 7th - 10th floor, Block-D, NINMAS, BSM Medical University Campus, Shahbag, Dhaka-1000, E-mail: israque_h@yahoo.com

\begin{abstract}
Objective: The aim of the present study is to determine the own normal range of T3, T4, FT4, \& TSH by two kits, one from Korea and another from China in the laboratory of healthy individuals from different divisions of the Institute.

Subjects and Methods: Fifty eight (58) adult individuals (39 male \&19 female) from different divisions of NINMAS were taken this study. The Korean kit contained coated tube and automated radioimmunoassays (RIA) were performed in case of the Korean kit. Radioimmunoassays with the China kit were done manually by counting in STRATEC $-\gamma$ Counter of Germany. Immunoassays of T3, T4, and FT4 were done by RIA method. With both the Korean and Chinese kit, TSH assays were performed by IRMA method.

Results: The results are analyzed by determining a mean \pm 2SD for the normal range. This assumes a Gaussian distribution for the analyte and automatically classifies $5 \%$ of the healthy individuals as abnormal. The normal range of T3, T4, FT4 and TSH done by Korean kit were $0.473732561-\mathbf{1 . 8 2 2 4 5 4 3 3 0 1 n g / m l ~ ( L e a f l e t ~ n o r m a l ~}$ range, $0.60-2.10 \mathrm{ng} / \mathrm{ml}$ ), 73.61233952- 152.00007428ng/ml (Leaflet normal range, $45.00-120.00 \mathrm{ng} / \mathrm{ml}), \quad 7.407195952-$ $21.673838528 \mathrm{ng} / \mathrm{ml}$ (Leaflet normal range, $9.01-23.17 \mathrm{ng} / \mathrm{ml}$ ) and 0.077556152 - 5.462788676 $\mu \mathrm{IU} / \mathrm{ml}$ (Leaflet normal range, 0.30 $5.00 \mathrm{ng} / \mathrm{ml}$ ) respectively. The normal range of T3, T4, FT4, and TSH done by China kit were 0.922455645 - $1.929268493 \mathrm{ng} / \mathrm{ml}$ (Leaflet normal range, $0.80-2.30 \mathrm{ng} / \mathrm{ml}), 44.87278419-141.23445719 \mathrm{ng} / \mathrm{ml}$ (Leaflet normal range, 42.00 - 135.00ng/ml), 5.80024859 32.72492383Pmol/L (Leaflet normal range, $9.50-25.50 \mathrm{Pmol} / \mathrm{L}$ ) and 0.807976292 - 5.77167888mIU/L. (Leaflet normal range, 0.30 $5.00 \mathrm{mIU} / \mathrm{L}$ ) respectively.

Conclusion: By estimating few more samples we may use our won estimated normal ranges instead of the leaflet normal ranges.
\end{abstract}

Key Words: In-vitro Lab, RIA, IRMA, Kits, Thyroid and its related Hormones.

\section{INTRODUCTION}

Normal values of analyte are usually determined by taking several hundred samples from normal population. If we estimate the mean $\mathrm{m}$ and standard deviation $s$ of data from normal population we can estimate the normal range as $\mathrm{m}-2 \mathrm{~s}$ to $\mathrm{m}+2 \mathrm{~s}$. This leaves $5 \%$ ( $2.5 \%$ below \& $2.5 \%$ above) of normal's outside the normal range, which is the set of values within which $95 \%$ of measurements from apparently healthy individuals will lie. By normal population we mean the apparently healthy members of local population. In this study samples are taken from normal people of different divisions of the institute (NINMAS) from different devisions of the Institute. The aim of the present study is to establish the own normal ranges of T3, T4, FT4, \&TSH by two kits, one from Korea and another from China, for the laboratory instead of using leaflet normal ranges.

\section{SUBJECTS AND METHODS}

Fifty eight (58) adult individuals (39 male \&19 female) from were different division of NINMAS in this study. The Korean kit contained coated tube and automated radioimmunoassays (RIA) were performed in case of the Korean kit1. Radioimmunoassays with the China kit2 were done manually by counting in STRATEC- $\gamma$ Counter of Germany. Immunoassays of T3, T4, and FT4 were done by RIA method. With both the Korean and Chinese kit, TSH assays were performed by IRMA method.

\section{RESULTS}

The results are analyzed by determining a mean \pm 2SD for the normal range. This assumes a Gaussian distribution for the analyte and automatically classifies $5 \%$ of the healthy individuals as abnormal. The average of $\mathrm{T} 3$ done by Korean kit was 
$1.149137931 \mathrm{ng} / \mathrm{ml}$ and the normal range was $0.4735932561-1.8246783301 \mathrm{ng} / \mathrm{ml}$. The average of T3 done by China kit was $1.42582069 \mathrm{ng} / \mathrm{ml}$ and the normal range was $0.922455645-1.929268493 \mathrm{ng} / \mathrm{ml}$. The average of $\mathrm{T} 4$ done by Korean kit was $112.8062069 \mathrm{ng} / \mathrm{ml}$, and the normal range was $73.61233952-152.00007428 \mathrm{ng} / \mathrm{ml}$. The average of T4 done by China kit was $93.05362069 \mathrm{ng} / \mathrm{ml}$ and the normal range was 44.87278419 $141.27125475 \mathrm{ng} / \mathrm{ml}$. The average of FT4 done by Korean kit was $14.54051724 \mathrm{ng} / \mathrm{ml}$ and the normal range was $7.407195952-21.673838528 \mathrm{ng} / \mathrm{ml}$. The average of FT4 done by China kit was $19.26258621 \mathrm{Pmol} / \mathrm{L}$ and the normal range was $5.80024859-32.72492383 \mathrm{Pmol} / \mathrm{L}$. The average of TSH done by Korean kit was $2.770172414 \mu \mathrm{IU} / \mathrm{ml}$ and the normal range was 0.077556152 $5.462788676 \mu \mathrm{IU} / \mathrm{ml}$. The average of TSH done by China kit was $3.289827586 \mathrm{mIU} / \mathrm{L}$ and the normal range was $0.807976292-5.77167888 \mathrm{mIU} / \mathrm{L}$. The above results with the corresponding SD (standard deviation) and estimated normal ranges were listed in the table 1. Graphical representation of the findings of T3, T4, FT4 and TSH immunoassays were also given

Table 1. Table for normal ranges

\begin{tabular}{|c|c|c|c|c|}
\hline $\begin{array}{l}\text { Origin of } \\
\text { Kit }\end{array}$ & $\begin{array}{l}\text { Hormone } \\
\text { Tested }\end{array}$ & Average & $\begin{array}{c}\text { SD } \\
\text { (Standard Deviation) }\end{array}$ & Normal Range (Average $\pm 2 \mathrm{SD}$ ) \\
\hline Korea & T3 RIA & $1.149137931 \mathrm{ng} / \mathrm{ml}$ & $0.337702685 \mathrm{ng} / \mathrm{ml}$ & $\begin{array}{l}0.47-1.82 \mathrm{ng} / \mathrm{ml}(\text { Own estimated }) \\
(0.60-2.10 \mathrm{ng} / \mathrm{ml}) \text { Leaflet Value }\end{array}$ \\
\hline China & T3 RIA & $1.42582069 \mathrm{ng} / \mathrm{ml}$ & $0.251703212 \mathrm{ng} / \mathrm{ml}$ & $\begin{array}{l}0.92-1.93 \mathrm{ng} / \mathrm{ml}(\text { Own estimated }) \\
(0.80-2.30 \mathrm{ng} / \mathrm{ml}) \text { Leaflet Value }\end{array}$ \\
\hline Korea & T4 RIA & $112.8062069 \mathrm{ng} / \mathrm{ml}$ & $19.59693369 \mathrm{ng} / \mathrm{ml}$ & $\begin{array}{l}73.61-152.00 \mathrm{ng} / \mathrm{ml} \text { (Own estimated) } \\
(45.00-120.00 \mathrm{ng} / \mathrm{ml} \text { ) Leaflet Value }\end{array}$ \\
\hline China & T4 RIA & $93.05362069 \mathrm{ng} / \mathrm{ml}$ & $24.09041825 \mathrm{ng} / \mathrm{ml}$ & $\begin{array}{l}44.87-141.23 \mathrm{ng} / \mathrm{ml}(\text { Own estimated) } \\
(42.00-135.00 \mathrm{ng} / \mathrm{ml} \text {.)Leaflet Value }\end{array}$ \\
\hline Korea & FT4 RIA & $14.54051724 \mathrm{ng} / \mathrm{ml}$ & $3.566660644 \mathrm{ng} / \mathrm{ml}$ & $\begin{array}{l}7.41-21.67 \mathrm{ng} / \mathrm{ml} \text { (Own estimated) } \\
(9.01-23.17 \mathrm{ng} / \mathrm{ml}) \text { Leaflet Value }\end{array}$ \\
\hline China & FT4 RIA & $19.26258621 \mathrm{Pmol} / \mathrm{L}$ & $6.73116881 \mathrm{Pmol} / \mathrm{L}$ & $\begin{array}{l}5.80-32.72 \mathrm{Pmol} / \mathrm{L}(\mathrm{O} \text { (nn estimated }) \\
(9.50-25.50 \mathrm{Pmol} / \mathrm{L}) \text { Leaflet Value }\end{array}$ \\
\hline Korea & $\begin{array}{l}\text { TSH } \\
\text { IRMA }\end{array}$ & $2.770172414 \mu \mathrm{I} \mathrm{U} / \mathrm{ml}$ & $1.346308131 \mu \mathrm{IU} / \mathrm{ml}$ & $\begin{array}{l}0.08-5.46 \mu \mathrm{IU} / \mathrm{ml}(\text { Own estimated }) \\
(0.30-5.00 \mu \mathrm{IU} / \mathrm{ml}) \text { Leaflet Value }\end{array}$ \\
\hline China & $\begin{array}{l}\text { TSH } \\
\text { IRMA }\end{array}$ & $3.289827586 \mathrm{mIU} / \mathrm{L}$ & $1.240925647 \mathrm{mIU} / \mathrm{L}$ & $\begin{array}{l}0.81-5.77 \mathrm{mIU} / \mathrm{L}(\text { Own estimated }) \\
(0.30-5.00 \mathrm{mIU} / \mathrm{L}) \text { Leaflet Value }\end{array}$ \\
\hline
\end{tabular}

\section{Graphical representation:}

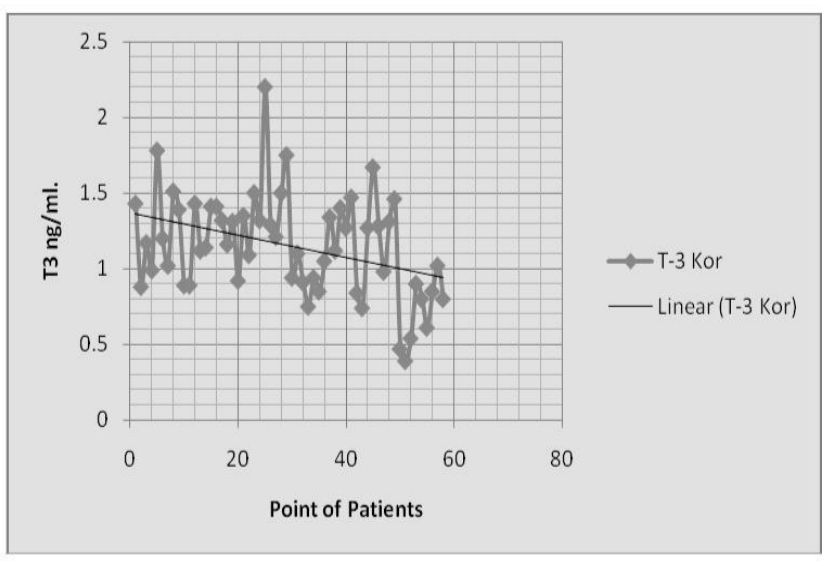

Figure 1. T3 RIA (Korea kit)

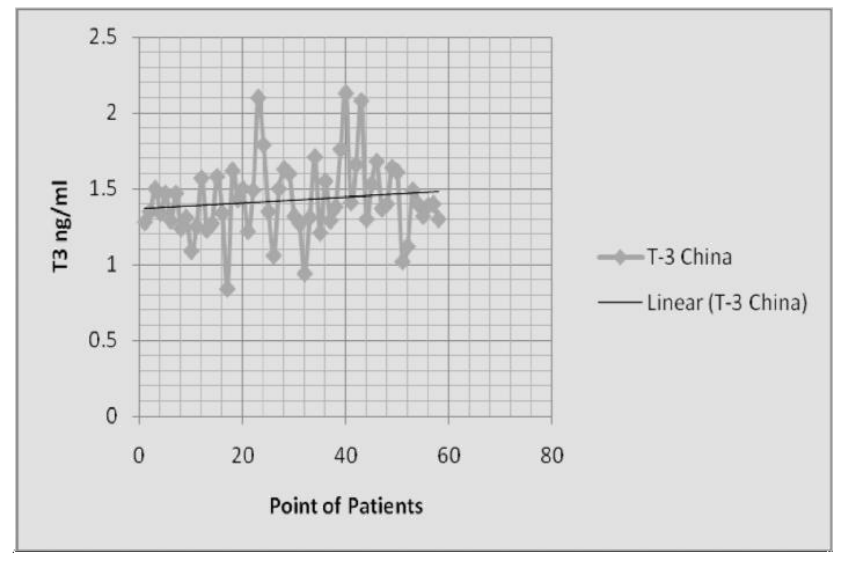

Figure 2. T3 RIA (China kit) 


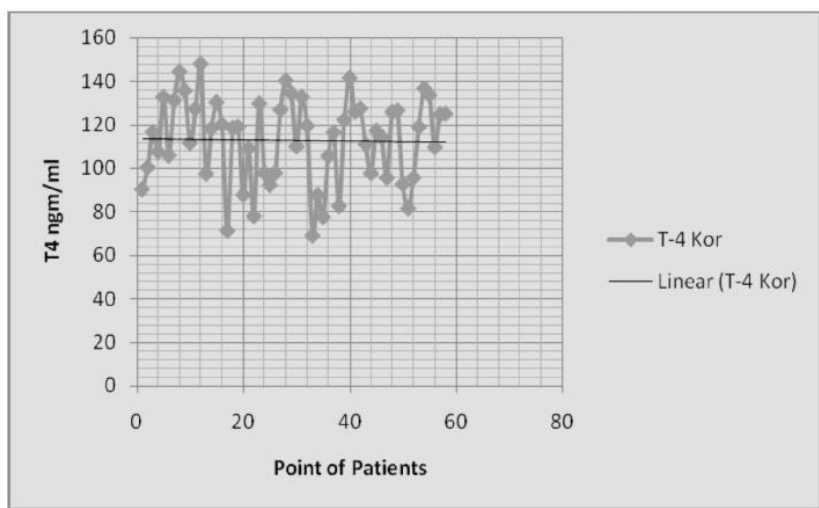

Figure 3. T4 RIA (Korea kit)

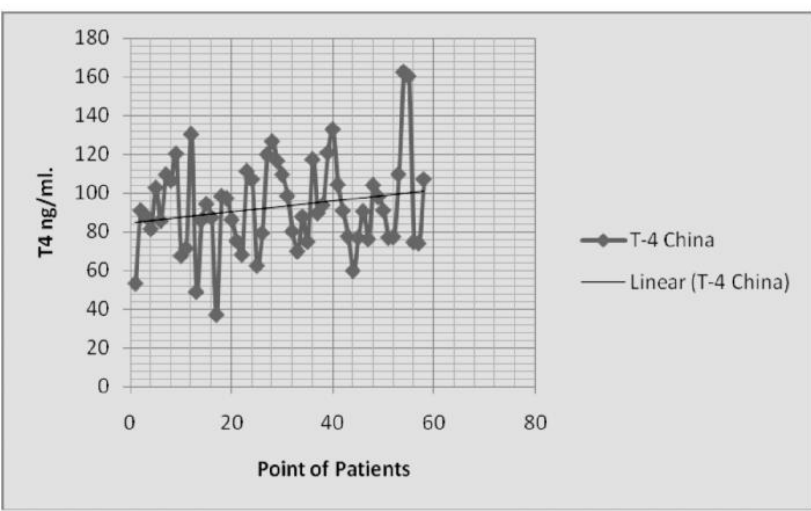

Figure 4. T4 RIA (China kit)

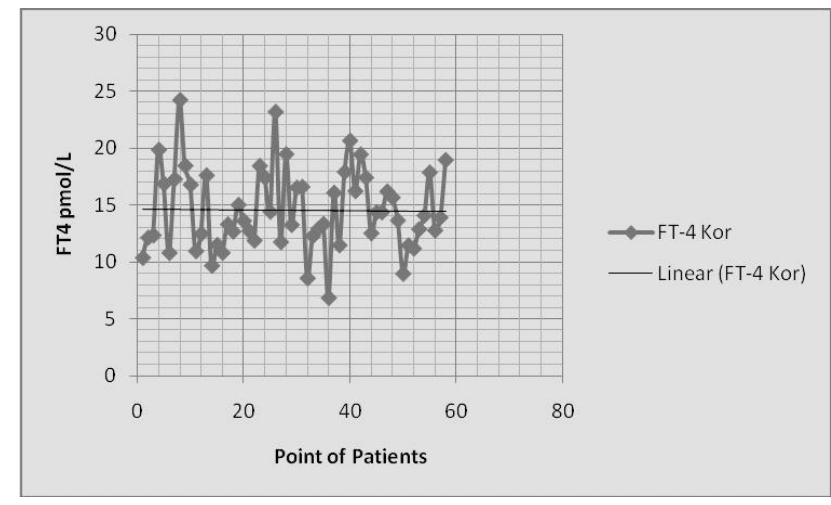

Figure 5. FT4 RIA (Korea kit)

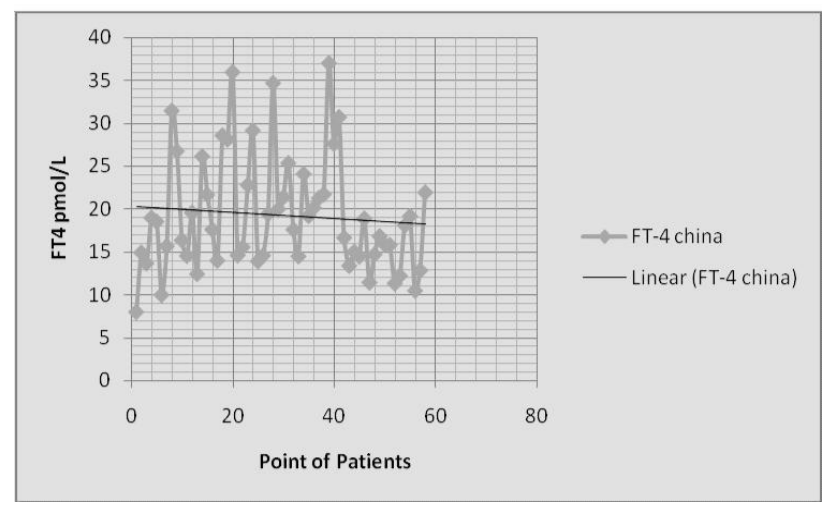

Figure 6. FT4 RIA (China kit)

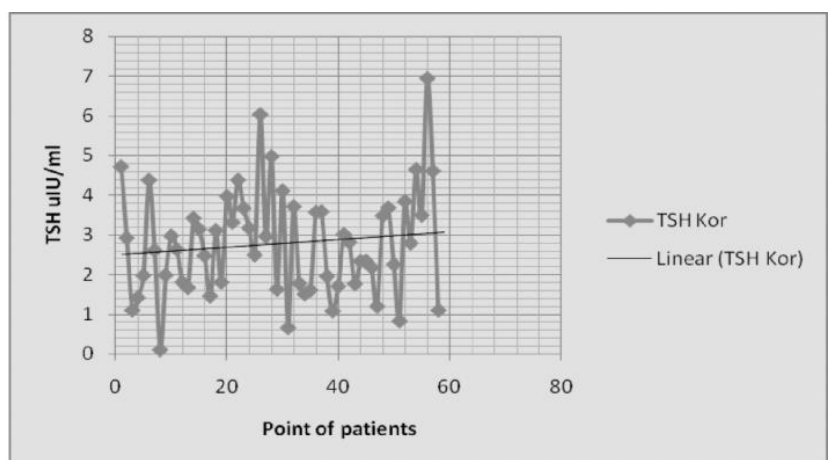

Figure 7. TSH IRMA (Korea kit)

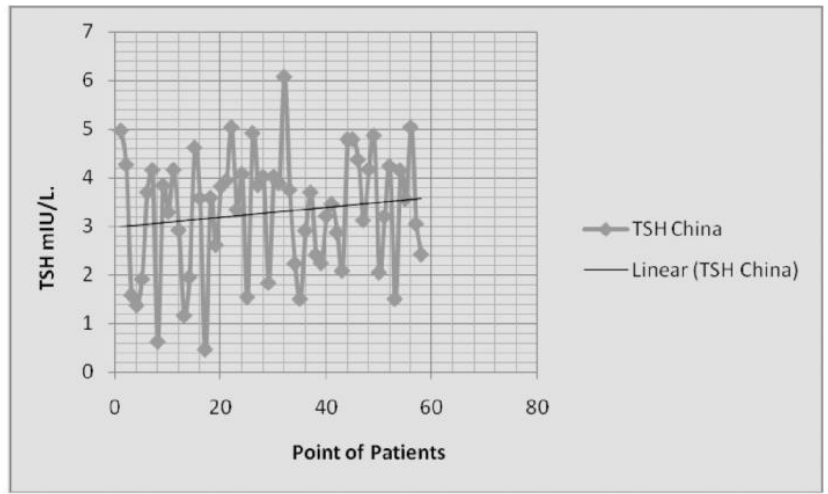

Figure 8. TSH IRMA (China kit)

(Figure $1-8$ ) for better explanation.

\section{DISCUSSION}

The estimated normal ranges of T3, T4, FT4, and TSH are compared with the leaflet normal ranges for both Korea and China kits. In case of T3 Korea both lower and upper ranges are less whereas for $\mathrm{T} 3 \mathrm{China}$ the lower range is higher and upper range is lower. In case of T4 Korea and T4 China both lower and upper ranges are higher. In case of FT4 Korea both lower and upper values are less whereas for FT4 China lower value is less and upper value is higher. In case of TSH Korea lower value is less and upper value is higher whereas for TSH China both lower and upper values are higher.

\section{CONCLUTION}

By estimating few more samples we may use our won estimated normal ranges instead of the leaflet normal ranges.

\section{REFERENCES}

1. Radioimmunoassay Manuals of T3, T4, FT4 and TSH assays; Shin Jin MEDICS INC. A405 Ilsan Techno Town, 138, Ilsan-ro, Ilsandong-gu,goyang-si, Gyeonggi-do, 410722, Republic of Korea, E-mail: diakey@ diakey.com

2. Radioimmunoassay Manuals of T3, T4, FT4 and TSH assays; Beijing North Institute of Biotechnology Co., Ltd. Pan Jiamiao A 20, Feng Tai District, Beijing, China, E-mail: bnibt@163.com 